\title{
Keefektifan Model Pembelajaran Role Playing dengan Media Video Animasi terhadap Kemampuan Pemecahan Masalah Matematika
}

\author{
Nuari Nur Baeti \\ Universitas PGRI Semarang \\ Betynuari98@gmail.com \\ Dwi Prasetiyawati \\ Universitas PGRI Semarang \\ Wawan Priyanto \\ Universitas PGRI Semarang
}

\begin{abstract}
The use of role playing learning model can help understanding the concept of students against, math because it involves students in the process learning so that students are not monotonous. In addition, the researchers added innovation in the study to show video animation learning to be more fun, students and ease in understanding material. This study using the experimental methods with the design preexperimental. After the action in this research, learning outcomes students has increased from pretest to posttest. Based on pretest a raid by researchers, note that the average pretest students only 29,75 or with mastery learning classical $0 \%$, with this 20 students or $100 \%$ students have completed. Thus it can be said that the students at the time pretest not maximum. After them doing the pretest, provides treatment students with use the model role playing a video animation as many as 2 meetings. Later in the end of the meeting them doing the posttest and the average value obtaining a 70,8 with mastery learning classical reached $75 \%$ or 15 students going and 5 students or $25 \%$ students have completed. So it can be said that the results maximum.
\end{abstract}

Keywords: Role playing, learning model, learning media, problem solving mathematics.

\section{Pendahuluan}

Penelitian ini dilatar belakangi berdasarkan tujuan pembelajaran di Sekolah Dasar adalah agar siswa mampu dan kreatif dalam mengaplikasikan matematika dalam kehidupan sehari-hari siswa. Sebagaimana dijelaskan pada Undang-Undang Nomor 20 Tahun 2003 tentang Sistem Pendidikan Nasional Pasal 67 ayat (3) menyebutkan bahwa: Pendidikan dasar bertujuan membangun landasan bagi berkembangnya potensi peserta didik agar menjadi manusia yang: 1) beriman dan bertakwa kepada Tuhan Yang Maha Esa, berakhlak mulia, dan berkepribadian luhur; 2) berilmu, cakap, kritis, kreatif, dan inovatif; 3) sehat, mandiri, dan percaya diri; dan 4) toleran, peka sosial, demokratis, dan bertanggung jawab (Barnawi, 2013:45).

Dari tujuan tersebut disimpulkan bahwa dalam belajar matematika siswa tidak hanya mendapatkan materi sesuai dengan kurikulum, namun mengaitkan materi dengan kehidupan nyata dan memberi pengalaman berlajar yang menyenangkan sehingga dalam mengajarkan matematika dapat mempunyai makna dan siswa dapat menggunakan kemampuannya dalam pembelajaran matematika. Hal ini juga sesuai 
dengan Kurikulum Tingkat Satuan Pendidikan (KTSP) yang menekankan dalam setiap kesempatan pembelajaran matematika hendaknya dimulai dengan pengenalan masalah yang sesuai situasi (Depdiknas, 2006 : 415).

Banyaknya siswa yang berpikiran bahwa matematika merupakan mata pelajaran yang sulit karena keabstrakan konsepnya, sedangkan anak usia SD yaitu 7 tahun hingga 12 atau 13 tahun daya pikir pada umumnya masih berfikir secara konkret dan belum dapat memahami sesuatu yang bersifat abstrak. Selain itu anak-anak usia SD cenderung lebih senang bergerak, bermain secara berkelompok dan senang melakukan aktivitas secara langsung. Mengaitkan materi pembelajaran masalah matematika dengan kejadian dikehidupan sehari-hari hal ini akan membantu siswa SD kelas III dalam memahami materi, terutama yang berhubungan dengan menghitung atau, materi tersebut membutuhkan keterampilan dan kemampuan untuk memecahkan masalah. Tidak hanya mengaitkan materi dengan kehidupan nyata, namun memberi pengalaman kepada siswa mengenai kegiatan yang pernah dilakukan oleh mereka atau sering dilakukan masyarakat dilingkungannya sehingga akan memberi motivasi belajar dan membantu siswa aktif dalam pembelajaran matematika. Gagne dalam Dimyati (2015:10), mengemukakan bahwa setelah belajar orang dapat memiliki pengetahuan, sikap, keterampilan, dan nilai. Timbulnya kapabilitas tersebut adalah berasal dari stimulus di lingkungan, dan dari pembelajaran.

Guru adalah agen sebagai penyalur perubahan dalam pendidikan, yang mana guru sebagai peran penggiat kepada siswa yang memiliki kodrat yang tidak terpisahkan dari lingkungan kehidupannya. Dalam melaksanakan tugasnya, guru sebaiknya memiliki kemampuan dalam perencanaan untuk menciptakan lingkungan belajar yang kreatif, inovatif dan kondusif bagi siswa-siswanya. Namun guru bukanlah salah satu sumber belajar, tetapi dengan posisinya sebagai peran penggiat, guru dapat mencipta sumber belajar yang lain yang dikenal sebagai media pembelajaran.Dimana media pembelajaran ini sebagai pendukung untuk menyampaikan materi yang diajarkan sehingga dapat membantu siswa memahami materi yang diberikan. Menurut Munadi (2013:7-8) media dapat membantu menyalurkan pesan dari sumber secara terencana sehingga menciptakan lingkungan belajar yang kondusif dimana penerimanya dapat melakukan proses belajar secara efektif dan efisien. Merujuk pada Kompas (2016:11) tidak ada yang statis dalam pendidikan yang berkaitan dengan guru, fasilitas dan sistem. Hal ini karena ilmu itu sendiri dinamis, jadi guru bisa menyesuaikan diri dengan membuat metode atau model pembelajaran yang membantu siswa dalam memahami konsep dari materi yang diberikan sesuai kebutuhannya. Menurut Bloom dalam Susanto (2013:6), mengatakan bahwa pemahaman konsep siswa didapat dari apa yang mereka pahami atau mengerti melalui apa yang mereka baca, yang dialami, yang dilihat atau yang mereka dapatkan berupa hasil penelitian atau observasi secara langsung yang akan menentukan seberapa kemampuan siswa menerima, menyerap, dan memahami pelajaran yang disampaikan oleh guru kepada siswa.

Hal ini karena ilmu itu sendiri dinamis, jadi guru bisa menyesuaikan diri dengan membuat metode atau model pembelajaran yang diberikan untuk membantu siswa dalam memahami konsep dari materi yang diberikannya sesuai kebutuhan. Pembelajaran model Role Playing adalah salah satu bentuk pembelajaran yang membantu guru dalam menyampaikan materi. Menurut Hadfield dalam Huda (2017:208), Role Playing dapat membantu siswa memahami materi dan melibatkan siswa dalam pembelajaran karena model pembelajaran ini berisi tentang permainan gerak yang didalamnya ada tujuan, aturan sekaligus melibatkan unsur senang.

Berdasarkan hasil observasi dan wawancara dengan siswa kelas III SD Negeri 02 Saradan-Pemalang dan dibantu guru kelas III diketahui bahwa kurangnya pemahaman siswa terhadap matematika dalam menyelesaikan soal pemecahan masalah matematika mengenai soal cerita yang masih kurang memberikan tahapan- 
tahapan jawabannya yaitu dengan menuliskan diketahui dan ditanya dari soal yang diberikan, dimana dari 20 siswa hanya 3 siswa yang mampu memahami bagian diketahui dan ditanya dari soal cerita yang diberikan namun belum bisa menuliskan tahapan-tahapan jawaban dari pemecahan masalah matematika dengan bentuk soal cerita yang diberikan sehingga hanya dapat menuliskan jawabannya, begitu juga dengan 17 siswa lainnya hanya memberikan hasil akhirnya tanpa memberikan tahapan-tahapan jawabannya, hal tersebut membuat peneliti meningkatkan kemampuan pemecahan masalah matematika siswa.

Selain itu, media pembelajaran belum sepenuhnya digunakan, sementara itu sarana prasarana di SDN 02 Saradan memadai tetapi belum maksimal sehingga alat bantu sebagai penunjang aktivitas belajar dan pemahaman siswa terhadap materi soal cerita tentang matematika rendah serta proses pembelajaran menjadi monoton. Hal ini mengakibatkan proses pembelajaran menjadi kurang menarik dan monoton sehingga kurang membantu siswa dalam pemahaman materi yang diberikan. Selain itu, siswa kelas III SDN 02 Saradan saat mengerjakan soal tersebut masih rendah dan minim akan pemahaman soal cerita yang berkaitan dengan pemecahan masalah matematika. Dengan demikian, memberikan contoh berdasarkan kejadian atau pengalaman yang pernah dialami oleh siswa tersebut akan membantu pemahaman materi siswa.

Adapun yang menjadi rumusan masalaadalah bagaimanakah keefektifan model pembelajaran role playing dengan media video animasi terhadap kemampuan pemecahan masalah Matematika siswa kelas III SD Negeri 02 Saradan-Pemalang?

Tujuan penelitian ini adalah untuk menganalisis keefektifan model pembelajaran role playing dengan media video animasi terhadap kemampuan pemecahan masalah Matematika siswa kelas III dan mewujudkan presentase siswa untuk memperoleh nilai sesuai dengan KKM (Kriteria Ketuntasan Minimal) yaitu 70 setelah tindakan yaitu $70 \%$ siswa tuntas.

Manfaat penelitian yaitu secara teoritis penelitian ini dapat dikembangkan di dunia pendidikan khususnya dalam pelajaran matematika agar siswa mampu memperbaiki kemampuan pemecahan masalah matematika. Bagi siswa yaitu: (1) Meningkatkan motivasi belajar siswa. (2) Membantu memecahan masalah matematika siswa kelas III SD Negeri 02 Saradan-Pemalang. (3) Suasana pembelajaran dalam kelas terlihat aktif dan tidak monoton. Bagi guru hasil penelitian ini diharapkan dapat dijadikan sebagai solusi guru dalam mengajarkan pemecahan masalah matematika dan mendorong untuk lebih kreatif dalam meningkatkan kualitas belajar melalui penggunaan media interaktif untuk membantu pemahaman konsep siswa terhadap matematika. Bagi Sekolah hasil penelitian ini diharapkan dapat memberikan masukan positif dalam meningkatkan mutu pendidikan dan menjadi alternatif model pembelajaran matematika dengan memanfaatkan fasilitas yang ada dengan baik untuk memudahkannya dalam mencapai tujuan pembelajaran.

\section{Metode}

Metode penelitian ini adalah eksperimen dengan desain penelitian pre-experimental. Karena terbentuknya variabel terikat masih terdapat pengaruh dari variabel luar atau variabel terikat tersebut bukan semata-mata dipengaruhi oleh variabel bebas. Sedangkan untuk metode penelitian ini menggunakan metode penelitian kuantitatif. Yaitu penelitian yang menggunakan angka sebagai bentuk represantatif dari hasil penelitian. Menurut Sugiyono (2015:108), bentuk desain eksperimen terdiri dari: PreExperimental Design, True Experimental Design, Factorial Design, dan Quasi Experimental Design. Namun dalam penelitian ini menggunakan Pre-Experimental Design dengan jenis One-Group Pretest-posttest Design. 
Desain ini observasi dilakukan sebanyak 2 kali yaitu sebelum diberikan treatment dan sesudah di berikan treatment. Observasi sebelum eksperimen ( $\mathrm{O} 1$ ) disebut pretest, dan observasi sesudah eksperimen ( $\mathrm{O} 2$ ) disebut posttest. Perbedaan antara O 1 dan O 2 yakni O 2 - O 1 diasumsikan merupakan efek dari treatment atau perlakuan saat diberikan model pembelajaran role playing dengan media video animasi. Pada desain penelitian ini, untuk mengetahui keadaan awal di kelas diberi pretest, selanjutnya kelas diberi perlakuan dengan menggunakan model role playing dengan media video animasi. Selanjutnya setelah diberi perlakuan diberi posttest.

Subjek penelitian ini digunakan dengan I sampel subjek penelitian. Subjek yang akan diteliti adalah siswa kelas III SD Negeri 02 Saradan Pemalang dengan jumlah 20 siswa. Sedangkan instrumen pada penelitian ini menggunakan test uraian yang berjumlah 20 soal. Serta melaksanakan test uji coba sebelum melaksanakan penelitian setelah melakukan uji coba maka selanjutnya diukur validitas, reliabilitas, taraf kesukaran, serta daya pembeda.

Penelitian ini menggunakan teknik pengumpulan data yaitu non tes dan tes. Non tes terdiri dari wawancara dan dokumentasi, wawancara tidak terstruktur dalam penelitian ini dilakukan bersama guru kelas III SDN 02 Saradan Pemalang. Dalam penelitian ini inti dari wawacara adalah mengenai proses pembelajaran matematika terutama pada materi pemecahan masalah matematika. Dokumentasi adalah sebagai bukti dan keterangan untuk menunjang keabsahan data. Penelitian ini menggunakan dokumentasi berupa proses pembelajaran, sampel tulisan jawaban uts pemecahan masalah matematika siswa pada soal cerita. Tes tertulis digunakan peneliti diakhir penelitian sebagai dasar penarikan kesimpulan dari penelitian. Tes hasil belajar ini dapat memberikan data-data yang digunakan sebagai tolak ukur tingkat keberhasilan yang dicapai oleh siswa dalam pelaksanaan penelitian. Tes hasil belajar akan diberikan pada saat pretest dan posttest.

Teknik analisis data dengan tahap analisis awal dengan cara melakukan uji normalitas, normalitas diperoleh untuk mengetahui normal tidaknya sebaran data Keefektifan Model Role Playing dengan Video Animasi terhadap Kemampuan Pemecahan Masalah Matematika Siswa Kelas III SDN O2 Saradan yang dianalisis. Uji normalitas yang digunakan adalah uji liliefors. Serta dilanjutkan tahap analisis Akhir, dan melakukan uji- t serta ketuntasan belajar siswa

\section{Hasil}

\section{Hasil Uji Validitas Butir Soal}

Dari hasil validitas yang telah dilakukan dengan menggunkan rumus korelasi product momment, soal yang berjumlah 20 terdapat 15 soal yang valid dan 5 soal tidak valid. 10 soal yang valid akan digunakan untuk instrumen penelitian dan 10 soal tidak digunakan sebagai instrumen penelitian.

\section{Hasil Uji Reliabilitas Butir Soal}

Dari uji validitas tersebut terdapat 15 soal yang valid maka dalam penelitian ini reliabilitas instrumen diuji dengan menggunakan rumus Alpha Cronbah. Dengan bantuan microsoft excel maka diperoleh $\mathrm{r} 11=0,9465$ dan $\mathrm{r}$ tabel $=0,444$ atau $\mathrm{r} 11>$ $r$ tabel maka instrumen dikatakan reliabel dan mendapat tingkat reliabilitas kriteria tinggi.

\section{Hasil Uji Taraf Kesukaran}

Taraf kesukaran mengukur tingkat mudah atau sulitnya suatu soal. Soal yang baik adalah soal yang tidak terlalu sulit dan tidak terlalu mudah. Soal yang terlalu mudah tidak mendorong siswa untuk mempertinggi usaha memecahkannya, adapun soal yang terlalu sulit membuat siswa putus asa. Dari analisis taraf kesukaran maka diperoleh hasil 7 butir soal dengan kategori sukar, dan 13 butir 


\section{Daya Pembeda Soal}

Daya pembeda soal merupakan kemampuan soal untuk membedakan antara siswa yang berkemampuan tinggi dengan siswa berkemampuan rendah (Arikunto, 2013: 226). Dari analisis daya pembeda soal dapat diperoleh hasil 10 butir soal kategori baik, 7 butir soal kategori cukup, dan 3 butir soal kategori jelek dari 20 soal.

\section{Hasil Uji Normalitas}

Uji Normalitas adalah pengujian terhadap normal tidaknya sebaran data yang dianalisis. Uji normalitas menggunakan lilliefors, dengan taraf signifikan $5 \%$. Kriteria dalam pengujian normalitas ini adalah jika Lhitung < Ltabel maka H0 diterima yaitu sampel berasal dari populas yang berdistribusi normal dan jika Lhitung < Ltabel maka H0 ditolak maka yaitu sampel berasal dari populasi yang berdistribusi tidak normal.

Nilai Pretest dengan jumlah siswa 20 dengan taraf signifkan 0,05 diperoleh L0 = 0,0807, Ltabel $=0,19$ dengan kriteria L0 < Ltabel maka berdistribusi normal.

Nilai Posttest dengan jumlah siswa 20 dengan taraf signifkan 0,05 diperoleh L0 = 0,178 , Ltabel $=0,19$ dengan kriteria L0 < Ltabel maka berdistribusi normal .

\section{Hasil Uji-t}

Setelah menghitung uji normalitas maka dilakukan uji-t. Berdasarkan perhitungan uji-t dapat diketahui bahwa thitung $=13,4865$, dan ttabel penelitian ini adalah 1,725 . Dengan kriteria jika thitung > ttabel maka H0 ditolak dan jika t hitung < ttabel maka H0 diterima. Maka pada penelitian ini H0 ditolak dan Ha diterima karena thitung $(13,4865)>$ ttabel $(1,725)$ yang berarti rata - rata hasil belajar siswa setelah menggunakan model pembelajaran Role Playing dengan Media Video Animasi lebih besar dari rata - rata hasil belajar siswa sebelum menggunakan model pembelajaran Role Playing dengan Media Video Animasi.

\section{Hasil Uji Ketuntasan}

Ketuntasan belajar klasikal mengukur ketuntasan belajar siswa satu kelas dengan cara membandingkan dengan kriteria ketuntasan belajar klasikal yang sudah ditetapkan yakni 75\%. Pada penelitian dikelas III SD Negeri 02 Saradan Pemalang ini mencapai presentase sebesar $75 \%$ yang artinya saat posttest kelas tuntas secara klasikal.

Tabel 4.1 Nilai Pretest dan Posttest

\begin{tabular}{cccc}
\hline Jenis Tes & Nilai Tertinggi & Nilai Terendah & Rata-rata \\
\hline Pretest & 36 & 20 & 29,75 \\
\hline Posttest & 85 & 32 & 70,80 \\
\hline
\end{tabular}

\section{Pembahasan}

Penelitian ini dilaksanakan pada bulan Juni 2019 di SDN 02 Saradan tahun pelajaran 2018/2019 pada kelas III dengan jumlah 20 siswa. Sebelum melaksanakan penelitian, peneliti melaksanakan observasi untuk mengetahui permasalahan yang ada di kelas dan diperoleh informasi bahwa dalam proses pembelajaran matematika khususnya pada kemampuan pemecahan masalah matematika siswa masih rendah. Hal itu ditunjukkan dengan hasil dokumentasi dan wawancara dengan siswa. Dengan adanya permasalahan tersebut peneliti memberikan perlakuan terhadap siswa dengan menggunakan model pembelajaran role playing dengan media video animasi pada pembelajaran matematika khususnya pada kemampuan pemecahan masalah matematika. 
Model pembelajaran yang dapat diterapkan untuk memberikan pembelajaran yang menyenangkan salah satunya adalah model pembelajaran role playing. Sesuai dengan Huda (2017:208), "Role Playing melibatkan siswa dalam proses pembelajaran sehingga membantu siswa lebih memahami materi karena model pembelajaran ini menggunakan permainan gerak yang didalamnya ada tujuan, aturan sekaligus keterlibatan". Model pembelajaran role playing tersebut dapat memberikan kesan berbeda dalam siswa dan mampu memberikan pembelajaran yang menyenangkan sehingga siswa tidak monoton. Peneliti juga menambahkan inovasi dengan menampilkan video animasi agar pembelajaran lebih menyenangkan, dan siswa dapat memahami materi dengan mudah.

Jenis penelitian ini bersifat penelitian kuantitatif. Penelitian ini menggunakan rancangan penelitian Pre-Experimental Design, namun desain penelitian ini masih terdapat pengaruh dari variabel luar terhadap variabel dependen sehingga belum merupakan eksperimen sungguh-sungguh, Sugiyono (2016:74). Bentuk desain yang digunakan adalah One-Group Pretest-Postest Design. Dalam desain ini menggunakan satu kelompok yaitu kelompok ekperimen dengan memberikan pretest sebelum diberi perlakuan dan memberikan posttest setelah diberi perlakuan. Hasil perlakuan dapat diketahui lebih akurat, karena membandingkan keadaan sebelum diberi perlakuan dengan keadaan setelah diberi perlakuan, Sugiyono (2016:74).

Dalam penelitian ini dilakukan uji persyaratan yang dilakukan setelah diberi tes hasil belajar pada kelompok sampel tersebut maka diperoleh data awal dan data akhir yang selanjutnya dilakukan analisis data awal dan data akhir. Analisis data awal diperoleh dari nilai pretest dan analisis data akhir diperoleh dari nilai posttest. Data hasil pretest harus dilakukan uji persyaratan analisis data, yaitu dengan uji normalitas awal.

Uji normalitas awal digunakan untuk mengetahui data yang diperoleh dari data yang memiliki distribusi normal atau tidak. Uji normalitas awal digunakan dengan menggunakan uji liliofers, dengan jumlah $\mathrm{n}=20$ dengan taraf nyata a $=0,05$ maka diperoleh Ltabel $=0,19$ dan Ltabel $=0,0807$, apabila nilai pretest $\mathrm{L} 0<\mathrm{Ltabel}$ dapat dikatakan berdistribusi normal. Berdasarkan nilai pretest tersebut L0 < Ltabel dengan demikian hipotesis atau H0 diterima, sehingga disimpulkan nilai pretest berasal dari data yang berdistribusi normal.

Uji persyaratan akhir dengan menggunakan uji normalitas akhir menggunakan nilai posttest. Uji normalitas akhir dengan jumlah $\mathrm{n}=20$ dengan taraf nyata a $=0,05$ maka diperoleh Ltabel $=0,19$ dan Ltabel $=0,1771$, apabila nilai posttest $\mathrm{L} 0<$ Ltabel dikatakan berdistribusi normal. Berdasarkan nilai posttest tersebut L0 < Ltabel dengan demikian hipotesis atau H0 diterima, sehingga disimpulkan nilai posttest berasal dari data yang berdistribusi normal.

Selanjutnya dilakukan uji t untuk menguji hasil belajar siswa berdasarkan nilai pretest sebelum diberi perlakuan dan nilai posttest sesudah diberi perlakuan dengan model pembelajaran role playing dengan media video animasi. Hasil dari perhitungan t-test diperoleh thitung sebesar 13,4865 dan ttabel sebesar 1,725 maka thitung > ttabel, sehingga H0 ditolak dan Ha . Dengan demikian dapat dinyatakan bahwa model Pembelajaran role playing dengan media video animasi efektif terhadap kemampuan pemecahan masalah. KKM pada pelajaran matematika adalah 70 untuk pretest nilai terendah adalah 20 dan nilai tertinggi adalah 36. Seluruh siswa atau 20 siswa tidak tuntas. Untuk posttest nilai terendah adalah 32 dan nilai tertinggi adalah 85 , dalam posttest ini siswa yang tuntas sebanyak 15 siswa dan siswa yang tidak tuntas sebanyak 5 siswa.

Penelitian ini relevan dengan penelitian penelitian yang dillakukan oleh Tien Kartini (2007) dengan judul "Penggunaan Metode Role Playing untuk Meningkatkan Minat Siswa dalam Pembelajaran Pengetahuan Sosial di Kelas V SDN Cileunyi I Kecamatan Cileunyi Kabupaten Bandung.”. Hasil penelitian tersebut menunjukkan 
bahwa metode role playing sangat efektif dalam meningkatkan minat belajar anak. Dimana pada siklus I ada 8 orang yang mengalami kesulitan dalam mengerjakan soal evaluasi, namun suasana senang dalam belajar sudah tampak. Siklus II, siswa yang awalnya mengalami kesulitan dalam mengerjakan soal evaluasi mulai berkurang dari 8 orang menjadi 4 orang dan siswa sudah berani dalam mengungkapkan pendapat dan berkomentar. Sementara itu, pada siklus III jumlah siswa yang merasa kesulitan dalam mengerjakan lembaran evaluasi menurun dan siswa lebih cepat menyelesaikan lembaran evaluasi dibandingkan dengan mengerjakan lembaran yang sama seperti pada siklus tindakan. Namun, penelitian yang dilakukan oleh tien kartini adalah pada mata pelajaran IPS sedangkan penelitian ini dilakukan pada pelajaran matematika.

Penelitian dari Wahyudi (2013) dalam dengan judul "Meningkatkan Karakter dan Hasil Belajar IPS Menggunakan Metode Bermain Peran pada Siswa SD”. Hasil penelitian menunjukkan bahwa proses pembelajaran IPS dengan penerapan metode bermain peran dapat meningkatkan karakter siswa. Dimana peningkatan tanggung jawab pada Siklus I, II, dan III secara berurutan $44,6 \%, 54,1 \%$, dan $64,1 \%$. Kejujuran pada Siklus I, II, dan III berturut-turut $42,85 \%, 52,9 \%$, dan $67 \%$. Kerja sama Siklus I, II, dan III memperoleh 42,14\%, 51,9\%, dan 62\%. Sedangkan Peningkatan hasil belajar pada Siklus I, II, dan III berturut-turut 66,5, 72,92 dan 74,85. Jadi, penerapan metode bermain peran dapat meningkatkan karakter dan hasil belajar siswa kelas IV SDN Tridadi Sleman.

Berdasarkan kajian teori, penelitian yang relevan dan setelah dilakukan pengujian hipotesis dapat disimpulkan bahwa penggunaan model pembelajaran role playing dengan media video animasi efektif terhadap kemampuan pemecahan masalah siswa kelas III.

Pada pembelajaran dengan menggunakan model pembelajaran role playing dengan media video animasi membuat siswa lebih senang saat pembelajaran berlangsung dan lebih mudah memahami materi yang diberikan. Sedangkan pada proses pembelajaran biasanya siswa lebih banyak mendengarkan penjelasan dari guru dikelas sehingga siswa lebih pasif sebagai penerima pengetahuan.

\section{Simpulan}

Berdasarkan penelitian dan analisis data yang dilakukan maka disimpulkan bahwa model pembelajaran role playing dengan media video animasi efektif terhadap kemampuan pemecahan masalah matematika siswa kelas III SDN 02 Saradan Pemalang. Dibuktikan dari hipotesis penggunaan model pembelajaran Role Playing dengan media video animasi efektif terhadap kemampuan pemecahan masalah matematika siswa kelas III SDN 02 Saradan Pemalang diterima. Hasil posttest pada kelas III SDN 02 Saradan Pemalang sesudah menggunakan model pembelajaran role playing dengan media video animasi lebih baik dari nilai pretest sebelum menggunakan model pembelajaran role playing dengan media video animasi yang dibuktikan dari rata-rata hasil belajar siswa berdasarkan pada hasil pretest yang telah dilakukan diperoleh sebesar 29,75 dan rata-rata nilai posttest yang diperoleh sebesar 70,80. Dibuktikan pula dari hasil uji t diperoleh thitung sebesar 13,4865 dan ttabel sebesar 1,729 maka thitung lebih besar dari ttabel sehingga model pembelajaran role playing dengan media video animasi efektif.

\section{Saran}

1. Model pembelajaran role playing dengan media video animasi dalam pembelajaran matematika dapat digunakan untuk meningkatkan kemampuan pemecahan masalah matematika siswa dengan dipadukan media yang menarik. 
2. Siswa diharapkan untuk bisa berpartisipasi secara aktif agar tujuan pembelajaran tercapai secara optimal.

3. Guru dapat mengembangkan model pembelajaran role playing dengan media video animasi dengan teknik atau model pembelajaran lainnya. Sehingga akan diperoleh model pembelajaran lainnya yang lebih menarik sesuai dengan karakteristik materi dan kemampuan siswa disekolah dasar.

\section{Referensi}

Barnawi dan Arifin. 2013. Strategi dan Kebijakan Pembelajaran Pendidikan Karakter. Jogjakarta: Ar-Ruzz Media.

Depdiknas. 2006. Kurikulum Tingkat Satuan Pendidikan (KTSP). Jakarta: Departemen Pendidikan Nasional.

Dimyati dan Mudjiono. 2015. Belajar dan Pembelajaran. Jakarta: Rineka Cipta.

Hamdayama, Jumanta. 2014. Model dan Metode Pembelajaran Kreatif dan Berkarakter. Bogor: Ghalia Indonesia.

Huda, Miftahul. 2013. Model-model Pengajaran dan Pembelajaran. Yogyakarta. Pustaka Pelajar.

Kartini, Tien. 2007. Penggunaan Metode Role Playing untuk Meningkatkan Minat Siswa dalam Pembelajaran Pengetahuan Sosial di Kelas V SDN Cileunyi I Kecamatan Cileunyi Kabupaten Bandung. Jurnal Pendidikan Dasar. No. 8. http://file.upi.edu/Direktori/JURNAL/PENDIDIKAN_DASAR/Nomor_8-

Oktober_2007/Penggunaan_Metode_Role_Playing_untuk_Meningkatkan_Mina t_Siswa_dalam_Pembelajaran_Pengetahuan_Sosial_di_Kelas_V_SDN_Cileunyi _I_Kecamatan_Cileunyi_Kabupaten_Bandung.pdf

Kompas. 2016. Daya Imajinasi Siswa Lemah.

https://www.google.com/amp/s/amp.kompas.com/nasional/read/2016/12/15/23091 361/daya.imajinasi.siswa.lemah.

Munadi, Yudhi. 2013. Media Pembelajaran. Jakarta Selatan. Referensi (GP Press Group). http://repo.iain-tulungagung.ac.id/339/4/BAB\%20II.pdf. (BAB II oleh Indri).

Sugiyono. 2016. Metodologi Penelitian Kuantitatif Kualitatif dan $R \& D$. Bandung: Alfabeta.

Susanto, Ahmad. 2013. Teori Belajar dan Pembelajaran di Sekolah Dasar. Jakarta. Prenadamedia Group.

Wahyudi dan Suardiman. 2013. Meningkatkan Karakter Dan Hasil Belajar IPS Menggunakan Metode Bermain Peran pada Siswa SD. Jurnal Prima Edukasia. $1(2)$. 